\title{
Crab spiders of the families Thomisidae and Philodromidae (Arachnida: Araneae) from Iran ${ }^{1}$
}

\author{
Hirotsugu Ono ${ }^{1} \&$ Jochen Martens ${ }^{2}$ \\ ${ }^{1}$ Department of Zoology, National Science Museum, 3-23-1 Hyakunin-cho, Shinjuku-ku, Tokyo, 169-0073 Japan \\ E-mail: ono@kahaku.go.jp \\ ${ }^{2}$ Institut für Zoologie, Johannes Gutenberg-Universität, Saarstraße 21, 55099 Mainz, Germany \\ E-mail:martens@uni-mainz.de
}

\begin{abstract}
Spiders of the families Thomisidae and Philodromidae (Arachnida, Araneae) mainly collected in the mountainous areas of Iran in 1978 are taxonomically studied and classified into 21 species of 10 genera. Most species are illustrated and described on the basis of the present specimens. Except for only two species, Xysticus kulczynskii Wierzbicki 1902 and Synaema globosum (Fabricius 1775), already known from this country, 19 species are new records to the Iranian fauna. Of these, 14 species, Tmarus stellio Simon 1875, Xysticus ninnii Thorell 1872 (subsp. fusciventris Crome 1965), X. cristatus (Clerck 1758), X. kochi Thorell 1872, X. gallicus Simon 1875, Oxyptila nigrita Thorell 1875, Heriaeus spinipalpus Loerbroks 1983, Misumena vatia (Clerck 1758), Pistius truncatus (Pallas 1772), Runcinia lateralis (C. L. Koch 1838), Thomisus hilarulus Simon 1875, Philodromus longipalpis Simon 1870, P. cespitum (Walckenaer 1802), and $P$. emarginatus (Schrank 1803), are previously known to science, while five species are regarded as new and described under the names Xysticus marusiki, X. logunovi, X. pieperi, Oxyptila makidica, and O. lutosa.
\end{abstract}

Key words - Araneae, Thomisidae, Philodromidae, Iran, taxonomy, new species

A collection of crab spiders with a large variety in species was made during a zoological expedition to Iran conducted by J. Martens and H. Pieper between May and July 1978 and provided to a taxonomic study, which is presented herein. Although all the specimens were examined, and the frame of study was designed by the first author (H. Ono) shortly after the material was collected, the report has not been published for a long time. Finally in 1999, both the authors had an opportunity to complete this study at Mainz, Germany, with support of the University of Mainz and the Ministry of Education, Science, Sports and Culture, Japan. The results of the Japanese-German collaboration are reported in this paper.

Spiders of western and central Asia are poorly studied in comparison with those of central and northern Europe and far-eastern Asia. Iran is one of the countries whose spider fauna is especially little known. The number of species (only 163) in recent works of Iranian spiders made by Mozaffarian \& Marusik (2001) and Logunov, Marusik \& Mozaffarian (2001) indicates more than five times the number of species which should be present. This checklist comprises 12 species of the family Thomisidae and 5 species of Philodromidae hitherto recorded from Iran, that is, Xysticus audax (Schrank 1803), X. lanio C. L. Koch 1845, X. loeffleri

Results of the Iran Expedition 1978 of J. Martens and H. Pieper, No. 14: --For No. 13 see Senckenbergiana biol., 64: 393-427, 1984. - J. M. sponsored by Deutsche Forschungsgemeinschaft.
Roewer 1955, X. tristrami (O. Pickard-Cambridge 1872), Oxyptila aculipalpa Wunderlich 1995, O. simplex (O. Pickard-Cambridge 1862), O. grisea Roewer 1955, O. rauda Simon 1875, O. praticola (C. L. Koch 1837), Synaema globosum (Fabricius 1775), Misumenops tricuspidatus (Fabricius 1775), Thomisus onustus Walckenaer 1805, Tibellus oblongus (Walckenaer 1802), Thanatus vulgaris Simon 1870, Philodromus aureolus (Clerck 1758), $P$. dispar Walckenaer 1825, and P. margaritatus (Clerck 1758). An obscure species, Xysticus kulczynskii Wierzbicki 1902, was added to the Iranian fauna by Logunov, Marusik \& Koponen (2002). Komposch (2002) also recorded five species from Iran: Xysticus kulczynskii, Synaema globosum, Heriaeus graminicola (Doleschall 1852), Thomisus onustus and Philodromus praedatus O. Pickard-Cambridge 1871. Totally 14 thomisids and 6 philodromids were previously known from Iran. Type localities of Oxyptila grisea, $O$. aculipalpa and Xysticus loeffleri, described by Roewer (1955) and Wunderlich (1994) are situated in Iran.

Specimens of the present material were classified into 18 species of nine genera of Thomisidae and three species of one genus of Philodromidae (although spiders of the latter family are also called small huntsman spiders, those are treated here as crab spiders). Of these, only two species, Xysticus kulczynskii and Synaema globosum, are already known from Iran, while other 19 species perform new records including five previously undescribed species of the 
genera Xysticus and Oxyptila. Descriptions of the new species and some known species of geographical interest are given in the present paper.

\section{Materials and Methods}

The collection used for this study was made during a zoological expedition to Iran conducted by J. Martens and H. Pieper in the period between 21st May and 7th July 1978. The study area was confined to the northern and northwestern part of Iran in the Alborz (Elburz) Mountains between Teheran and the shore of the Caspian Sea mainly in the Province of Masandaran. On the map, the core area may be described being situated between Karaj in the southwest and Firuzkuh in the southeast, and towns of Babolsar and Chalus along the Caspian Shore. Another, even smaller study area was situated in the Province of Azerbaijan in the extreme northwest of Iran. Collecting sites in this area were selected mainly in the Arasbaran Wildlife Refuge around Kalan, Makidi and Kaleybar, northwest of Tabriz. [Azarbayejan is recently used for the province in Iran to distinguish it from the Caucasian country of Azerbaijan (D. Logunov, and Y. Marusik, pers. comm.).]

Altidudes and, consequently, habitats in the study areas are quite manifold comprising lowland habitats at sea level of the Caspian Sea to alpine meadows in the Alborz Mountains. Although the central Alborz Mountains rise to a height of $5670 \mathrm{~m}$, the collecting sites were limited up to 2900 m. Beech forests with Fagus orientalis prevail on the northern slopes of the mountains, and the forest floor is generally covered with moist soil and a rich leaf litter layer influenced by heavy Caspian precipitations. On the other hand, forest cover disappeared in most areas south of the Alborz main ridge since long because of heavy human timber over-exploitation in combination with much lower rainfall. Reforestation with cypress trees (Cupressus sp.) was occasionally observed in these areas.

Collecting sites in Azerbaijan were generally drier and forest cover was considerably reduced. In the Arasbaran Wildlife Refuge, remnant oak (Quercus sp.) bushes and low trees were protected around the village of Makidi, while alpine meadows including scattered bushes and small trees of Quercus, Viburnum, Rosa, Sorbus and Ribes prevailed around Kalan (2400 m alt.). However, this vegetation composition indicated that true alpine conditions were not fully developed at this altitude.

Spiders were collected by sifting soil litter, sweeping herbs and low bushes and by turning stones and rotten logs. Specimens of these spiders preserved in $75 \%$ alcohol were examined and partly dissected under a binocular stereomicroscope for identification at the Zoological Institute of the University of Mainz, Germany. All the specimens including types are deposited in the collection of the Section of Arachnology, Senckenberg Museum, Frankfurt am Main, Germany (SMF).

Abbreviations used in this paper are as follows: ALE, anterior lateral eye; AME, anterior median eye; MNHN, Mu- séum National d'Histoire Naturelle, Paris; PLE, posterior lateral eye; PME, posterior median eye. Terminology of descriptions follows Ono (1988).

\section{Taxonomy}

Family Thomisidae

Genus Tmarus Simon 1875

Tmarus stellio Simon 1875

(Figs. 1-4)

Specimens examined. 2 females and 3 males, Iran, Masandaran Province, Alborz Mountains, $25 \mathrm{~km} \mathrm{~S}$ of Amol, a western branch valley of Heraz, between 490 and $560 \mathrm{~m}$ alt., 29.VI.1978, J. Martens and H. Pieper leg. (SMF).

Comparative material. 1 male, Hungary, Tokaj, (Mezakl), (MNHN 5446); 1 female, 1 male and 3 juveniles, France, St. Audeol, Banyuls, (Sel), det. E. Simon (MNHN 693).

Notes. Male palp (Figs. 1-3) and epigynum (Figs. 4) are illustrated based on the material from Iran. No morphological differences in genital organs were recognized between the present specimens from Iran and the comparative specimens from Hungary and France.

Distribution. This species is widely distributed from southern Europe (France, Italy) to central Asia, and is closely related to Tmarus rimosus Paik 1973, known from China, Korea, Japan, and East to West Siberia (Ono 1988; Logunov 1992).

\section{Genus Xysticus C. L. Koch 1835, sensu lato \\ Xysticus ninnii Thorell 1872 \\ (subsp. fusciventris Crome 1965)}

(Figs. 5-12)

Specimens examined. 1 female, 1 male and 2 juveniles, Teheran Province, Alborz Mountains, near the pass above Polour, at $2350 \mathrm{~m}$ alt., 30.VI.1978, J. Martens and H. Pieper leg. (SMF).

Description based on the Iranian material. Measurements. Body length female $5.5 \mathrm{~mm}$, male $4.0 \mathrm{~mm}$; prosoma length female $2.6 \mathrm{~mm}$, male $2.1 \mathrm{~mm}$, width female $2.4 \mathrm{~mm}$, male $1.9 \mathrm{~mm}$; opisthosoma length female $3.4 \mathrm{~mm}$, male 2.0 $\mathrm{mm}$, width female $3.0 \mathrm{~mm}$, male $1.6 \mathrm{~mm}$; lengths of legs [total length (femur + patella + tibia + metatarsus + tarsus)]: female, I $7.68 \mathrm{~mm}(2.28+1.24+1.68+1.68+0.80)$, II 7.68 $\mathrm{mm}(2.40+1.16+1.68+1.68+0.76)$, III $5.32 \mathrm{~mm}(1.64+$ $0.92+1.20+0.96+0.60)$, IV $5.76 \mathrm{~mm}(1.64+0.84+1.24$ $+1.32+0.72)$, male I $7.64 \mathrm{~mm}(2.28+0.92+1.64+1.84$ $+0.96)$, II $7.40 \mathrm{~mm}(2.20+0.96+1.60+1.76+0.88)$, III $4.88 \mathrm{~mm} \quad(1.48+0.72+0.96+1.12+0.64), \quad$ IV $5.20 \mathrm{~mm}$ $(1.48+0.60+1.04+1.36+0.72)$.

Prosoma longer than wide (length/width female 1.08, 

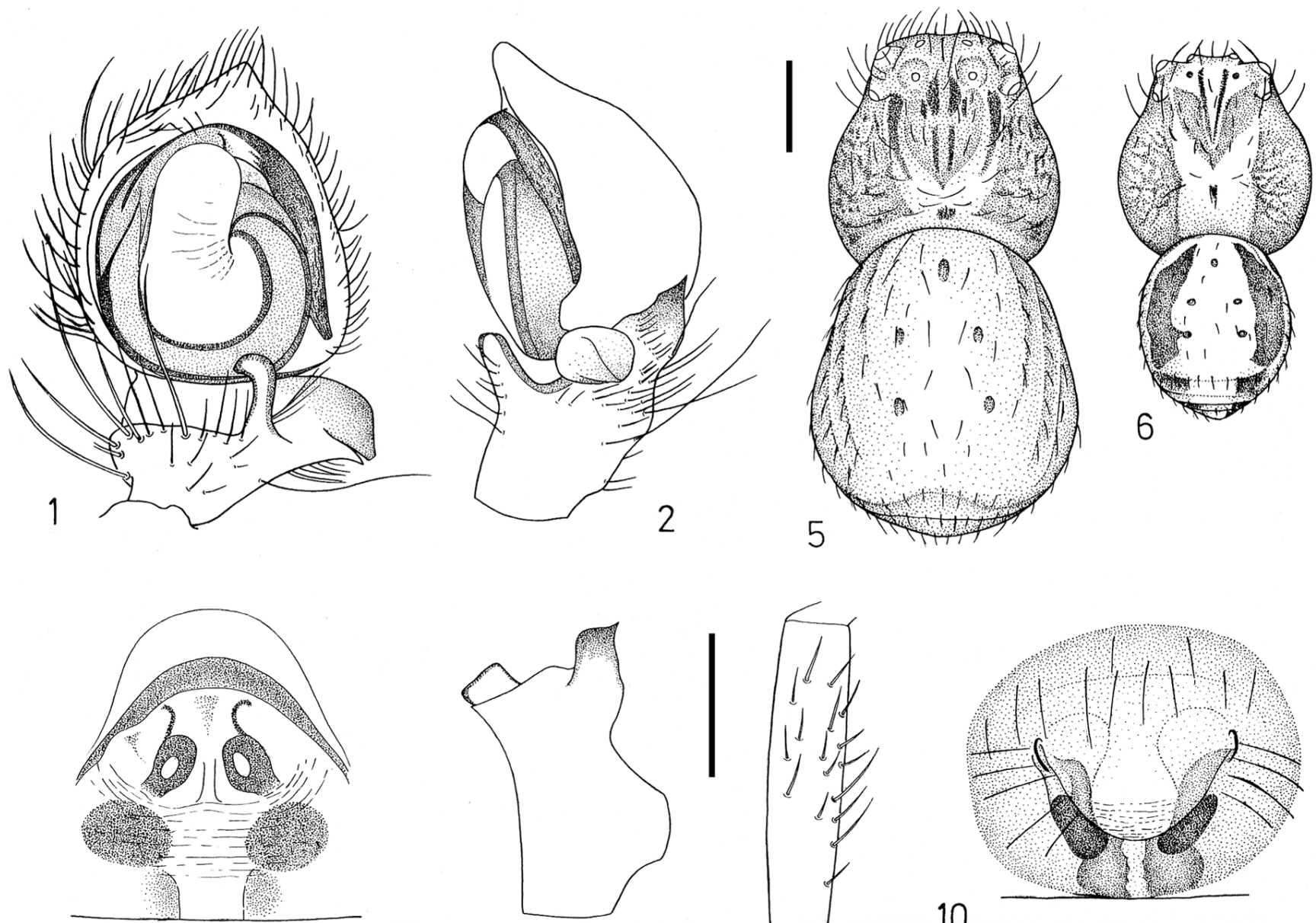

4
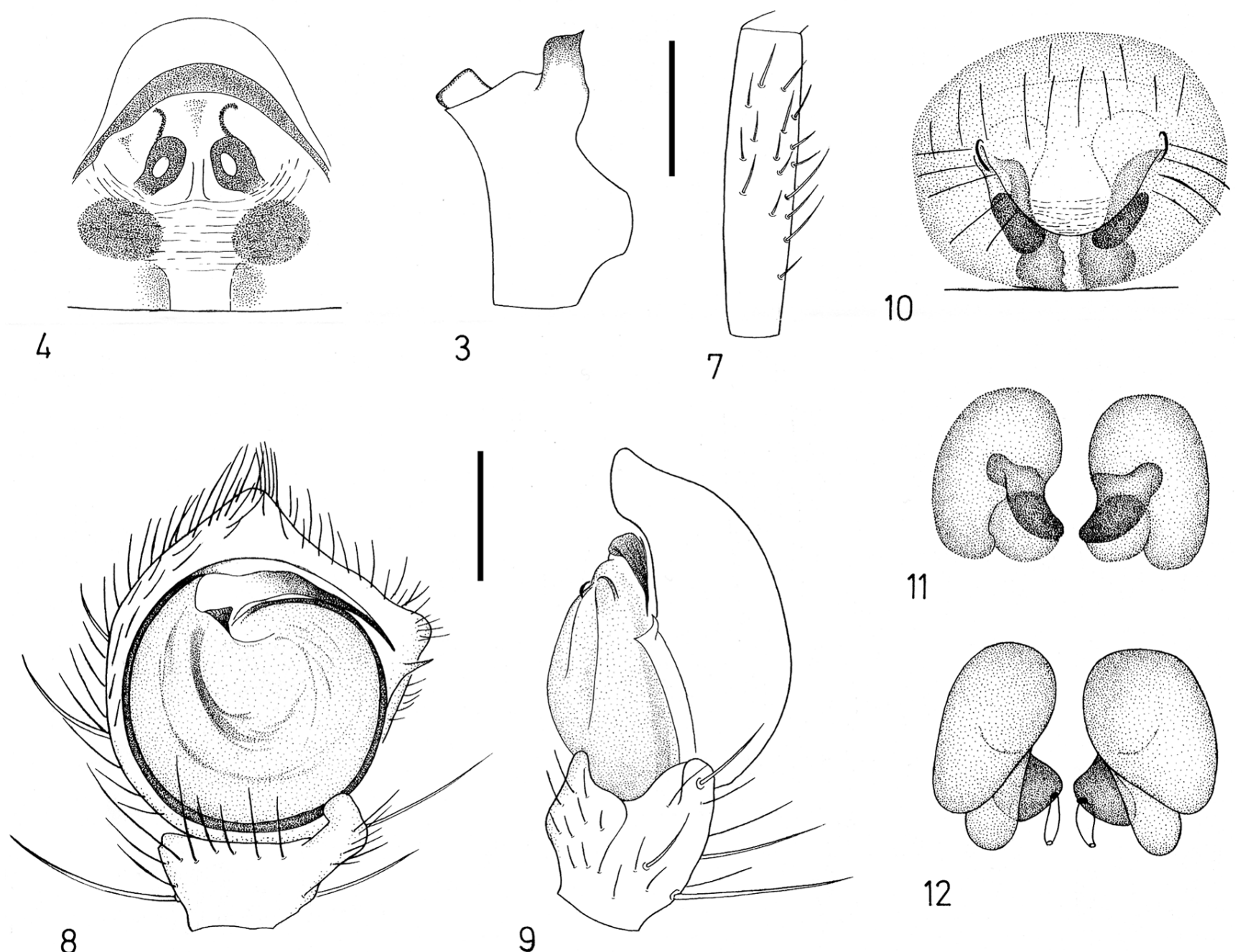

12

Figs. 1-12. 1-4, Tmarus stellio Simon 1875; 5-12, Xysticus ninnii fusciventris Crome 1965.-1, 8, Male palp, ventral view; 2, 9, male palp retrolateral view; 3, male palpal tibia, dorsal view; 4, 10, epigynum; 5, female body, dorsal view; 6, male body, dorsal view; 7, femur of the first leg of male, dorsal view; 11, female internal genitalia, ventral view; 12, female internal genitalia, dorsal view. [Scales: 1-4, 7$12,0.25 \mathrm{~mm} ; 5-6,1 \mathrm{~mm}$. 
male 1.11), with thin setae. Eyes: ALE $>$ PLE $>$ PME $\geqq$ AME, ALE/AME female 1.71, male 1.66, PLE/PME female 1.66, male 1.33, AME-AME/AME-ALE female 1.70, male 1.44, PME-PME/PME-PLE female 1.06, male 1.00, median ocular area wider than long (length/width female 0.81 , male 0.85 ), wider behind than in front (anterior width/posterior width female 0.88 , male 0.90 ), clypeus/AME-AME female 0.59 , male 0.62 . Labium longer than wide (length/width female 1.30, male 1.29), sternum longer than wide (length/ width female 1.19, male 1.14). Leg formula I-II-III-IV or I $=$ II-IV-III; tarsal claws of legs I-II with 4 or 5 teeth, IIIIV with 4 teeth.

Spination (spiniformation) of leg I, other legs omitted (for terminology see Ono 1988, p.13; same in following descriptions). Female: Femur: prolateral 1-1-1; tibia: ventral 1-2-2-2-2; metatarsus prolateral $2-1-1-0-2 \mathrm{ap}$, retrolateral 2-1-1-0-2ap, ventral 2-2-0-2. Male: Femur: dorsal and prolateral as in Fig. 7; tibia: prolateral $2-2-1$, retrolateral $1^{-}$ 1-1, ventral $2-2-2-2$; metatarsus: prolateral 1-1-2ap, retrolateral $0-1-1 \mathrm{ap}$, ventral $2-2-2$.

Male palp (Figs. 8-9). Tibia with a ventral and a retrolateral apophysis: the ventral apophysis wide and large, distally curved; the retrolateral one obtuse. Bulb large and round, as long as wide, without distinct apophysis, but a dentiform tegular ridge present in the distal part; embolus short and spiniform, apically sharpened.

Opisthosoma longer than wide (length/width female 1.13, male 1.25).

Female genitalia (Figs. 10-12). Epigynum wider than long, without median septum, but with a linguiform projection at the middle between both the intromittent orifices; intromittent orifices visible. Intromittent canal thick, short and not visible in dorsal view of the genitalia; spermathecae reniform with large cock.

Coloration and markings (Figs. 5-6). Female: Prosoma dark brown, lighter at the middle, chelicerae, maxillae, labium, sternum, legs and palps light yellowish brown. Opisthosomal dorsum beige without distinct marking, venter light yellowish brown. Male: Prosoma blackish brown, lighter at the middle, chelicerae, maxillae and labium light yellowish brown, sternum white, femur and patella of legs I and II black, other segments of legs and palps light yellowish brown. Opisthosomal dorsum beige, with a distinct, brown stripe on each side.

Distribution. This subspecies of Xysticus ninnii is widely distributed from the European part of Russia to Mongolia (Crome 1965; Utotchkin \& Savelyeva 1995). The present record seems to be the southernmost one in the distributional range of this subspecies.

\section{Xysticus marusiki sp. nov.}

(Figs. 13-23)

Type material. Female holotype and 1 male paratype, Alborz Mountains, Shemshak, at $2800 \mathrm{~m}$ alt., 24.VI.1978, J. Martens and H. Pieper leg. (SMF).

Other specimens examined. 1 female and 1 juvenile, Shemshak, birch forest, between 2850 and $2900 \mathrm{~m}$ alt., 22.VI.1978, same collectors (SMF).

Diagnosis. This species resembles Xysticus bakanas Marusik \& Logunov 1990, from Kazakhstan and X. kuzgi Marusik \& Logunov, 1990, from Uzbekistan in the structure of male palp, but can be distinguished from the two species by the details, especially the shape of embolus (cf. Figs. 1516 and Marusik \& Logunov 1990, p. 58, figs. 10-13). Epigynum of this new species is very unique in shape and easily distinguishable from that of other congeners. Females of Xysticus bakanas and X. kuzgi are unknown.

Description based on the female holotype and the single male paratype. Measurements. Body length female 5.3 $\mathrm{mm}$, male $4.0 \mathrm{~mm}$; prosoma length female $2.5 \mathrm{~mm}$, male 2.1 $\mathrm{mm}$, width female $2.3 \mathrm{~mm}$, male $2.1 \mathrm{~mm}$; opisthosoma length female $2.9 \mathrm{~mm}$, male $2.1 \mathrm{~mm}$, width female $2.5 \mathrm{~mm}$, male $1.8 \mathrm{~mm}$; lengths of legs [total length (femur + patella + tibia + metatarsus + tarsus) ]: female, I $6.84 \mathrm{~mm}(2.12+$ $1.12+1.40+1.48+0.72)$, II $6.88 \mathrm{~mm}(2.12+1.12+1.36+$ $1.48+0.80)$, III $4.92 \mathrm{~mm}(1.52+0.80+1.00+0.96+0.64)$, IV $5.48 \mathrm{~mm}(1.76+0.76+1.08+1.20+0.68)$, male I 6.64 $\mathrm{mm}(1.92+0.88+1.44+1.60+0.80)$, II $6.68 \mathrm{~mm}(1.96+$ $0.92+1.40+1.56+0.84)$, III $4.48 \mathrm{~mm}(1.40+0.64+0.92$ $+0.92+0.60)$, IV $4.80 \mathrm{~mm} \quad(1.56+0.60+0.92+1.08+$ $0.64)$.

Prosoma longer than wide or as long as wide (length/ width female 1.08, male 1.00), with thin setae. Eyes: ALE $>$ PLE $>$ PME $=$ AME, ALE $/$ AME female and male 2.00, PLE/PME female 1.66, male 1.33, AME-AME/AMEALE female 1.77, male 1.57, PME-PME/PME-PLE female 1.00 , male 0.86 , median ocular area wider than long (length/width female 0.80, male 0.94), wider behind than in front (anterior width /posterior width female 0.88 , male 0.94), clypeus/AME-AME female 0.75 , male 0.73 . Labium longer than wide (length/width female 1.20, male 1.50), sternum longer than wide (length/width female 1.18, male 1.13). Leg formula II-I-IV-III; tarsal claws of legs I-II with 4 or 5 teeth, III-IV with 3 or 4 teeth.

Spination of leg I. Female: Femur: prolateral $0^{-1-1-1^{-}}$

Figs. 13-29 (on the page 113). Xysticus spp. 13-23, Xysticus marusiki Ono \& Martens sp. nov.: 13-19, female holotype and male paratype from Shemshak, $2800 \mathrm{~m}$ alt., 20-23, a specimen (non type) from Shemshak, between 2850 and 2900 m alt.; 24-25, Xysticus cristatus (Clerck 1757); 26-29, Xysticus kochi Thorell, 1872.-13, 20, Female body, dorsal view; 14, 26, male body, dorsal view; 15, 24, 27, male palp, ventral view; 16, 25, 28, male palp, retrolateral view; 17, 21, epigynum; 18, 22, female internal genitalia, ventral view (18, with an intromittent orifice, lateral view); 19, 23, female internal genitalia, dorsal view; 29, tegular apophyses of male palp, ventral view. [Scales: 13-14, 20, 26, $1 \mathrm{~mm}$; 15-19, 21-25, 27-29, $0.25 \mathrm{~mm}$.] 

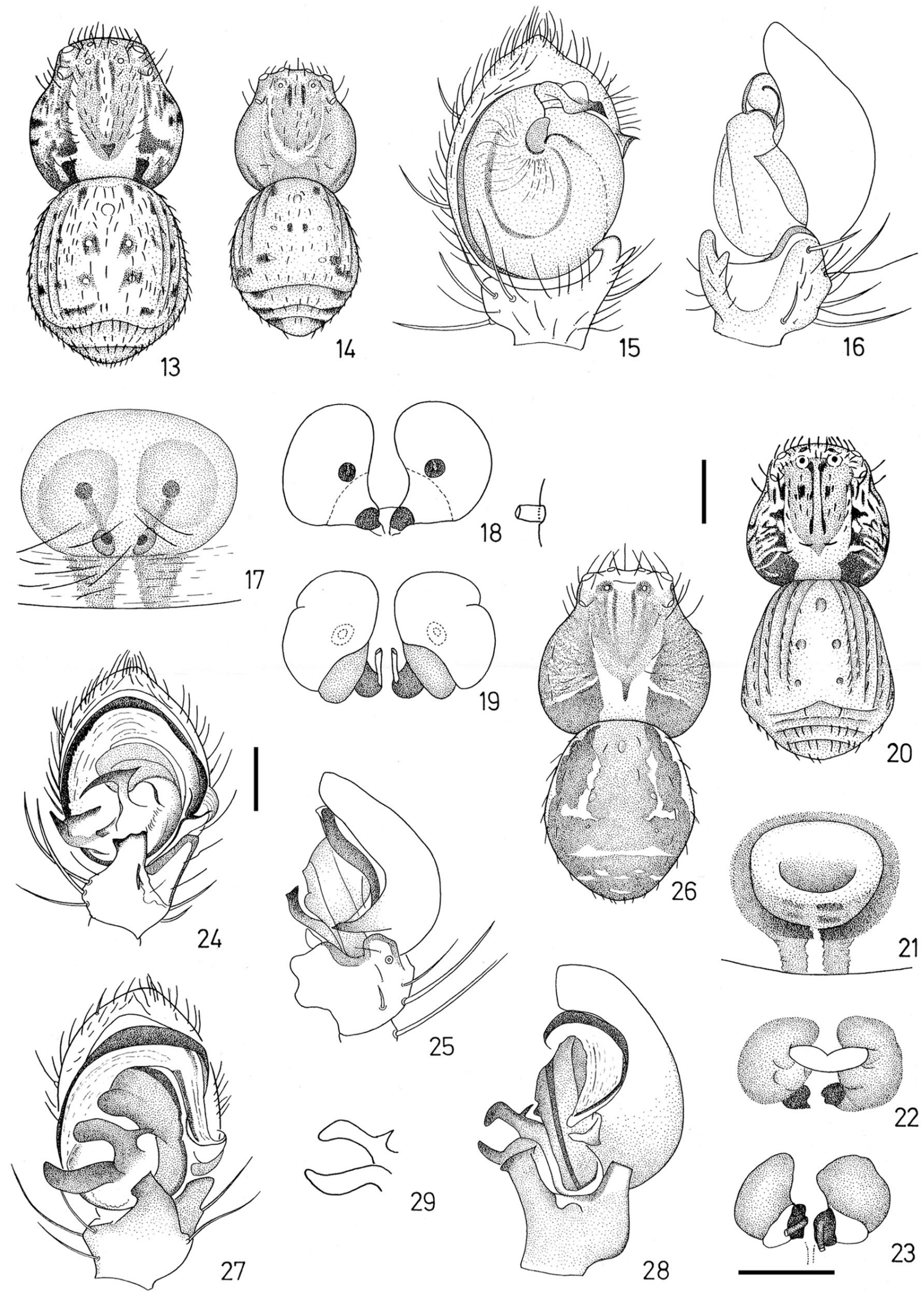
0; tibia: ventral 1-2-2-2; metatarsus prolateral 1-1-2ap, retrolateral 0-1-2ap, ventral 2-2-2. Male: Femur: dorsal 00-1-1-1-1, prolateral $1-1-1-1-1-1$; tibia: pro- and retrolateral $1-1-1$ respectively, ventral $2-2-2-2$; metatarsus: pro- and retrolateral $0-1-2$ ap respectively, ventral $2-2-$ 2.

Male palp (Figs. 15-16). Tibia with a ventral and a retrolateral apophysis: the ventral apophysis digitiform, distally curved and with a tooth; the retrolateral one obtuse, distally sclerotized. Bulb large and round, longer than wide, without distinct apophysis; embolus short, thick and twisted, apically rostrate.

Opisthosoma longer than wide (length/width female and male 1.16).

Female genitalia (Figs. 17-19). Epigynum wider than long, neither a median septum nor a projection at the middle between both the intromittent orifices; intromittent orifices visible. Intromittent canal thick, short and cylindrical, not visible in dorsal view of the genitalia; spermathecae ovate, with large cock.

Coloration and markings (Figs. 13-14). Female and male: Prosoma light blackish brown, with V-shaped white region at the middle, chelicerae, maxillae, labium, sternum and palps dark yellowish brown, femur and patella of legs I and II of male light blackish brown, other segments of legs I and II and all segments of legs III-IV of male and legs IIV of female light beige. Opisthosomal dorsum white with blackish brown spots, venter light beige.

Variation. The shape of the epigynum of the other female from Shamshek, 2850-2900 (non type) is different from that of the holotype (cf. Figs. 17, 21) and the opening part is covered by a membranous bridge (Fig. 22). Epigynum is swollen, almost as long as wide, and with a hollow at the middle, and the intromittent orifices are not visible. However, spermathecae of both the individuals are very similar in structure (Figs. 19, 23). Coloration and markings (Fig. 20) of the variant resemble those of the holotype with the exception of the paired black markings on posterior part of carapace larger than those of the holotype. Measurements of the variant female. Body length $4.8 \mathrm{~mm}$; prosoma length $2.1 \mathrm{~mm}$, width $2.0 \mathrm{~mm}$; opisthosoma length $2.8 \mathrm{~mm}$, width $2.3 \mathrm{~mm}$; lengths of legs [total length (femur + patella + tibia + metatarsus + tarsus $)]:$ I $5.52 \mathrm{~mm}(1.68+$ $0.96+1.20+1.12+0.56)$, II $5.68 \mathrm{~mm}(1.72+0.96+1.24$ $+1.12+0.64)$, III $4.04 \mathrm{~mm}(1.36+0.64+0.84+0.72+$ $0.48)$, IV $4.28 \mathrm{~mm}(1.36+0.64+0.92+0.84+0.52)$.

Distribution. Iran (known only from type locality).

Remark. This species is dedicated to Dr. Yuri M. Marusik in honor of his contribution in taxonomy of crab spiders.

\section{Xysticus cristatus (Clerck 1757)}

(Figs. 24-25)

Specimens examined. 2 males, Azerbaijan, Kalan, Arasbaran Wildlife Refuge, between 2450 and $2650 \mathrm{~m}$ alt., meadow, 6-10.VI.1978, J. Martens and H. Pieper leg. (SMF).

Notes. Male palp (Figs. 24-25) is illustrated on the basis of the Iranian specimen. Recently, Azarkina \& Logunov (2001) discussed speciation and distribution of Xysticus cristatus (Clerck 1757) and X. audax (Schrank 1803), and separated a new species, $X$. pseudocristatus Azarkina \& Logunov 2001, from Central Asia. Jantscher (2001) also studied diagnostic characters of Xysticus cristatus, X. audax and X. macedonicus Silhavy 1944. Referring to these papers, the present specimens display the typical shape of male palp of $X$. cristatus.

Distribution. Widely distributed in Eurasia. This record may perform the southernmost point in the distributional range of the species.

\section{Xysticus kochi Thorell 1872}

(Figs. 26-29)

Specimens examined. 2 females, Masandaran, $25 \mathrm{~km} \mathrm{~S}$ of Amol, a western branch valley of Heraz, between 490 and $560 \mathrm{~m}$ alt., Alborz Mountains, 29.VI.1978; 2 females, Masandaran, W of Pol-e-Doab, at $600 \mathrm{~m}$ alt., 31.V.1978; 1 male, Azerbaijan, Makidi, at $1700 \mathrm{~m}$ alt., oak bush; 7 females and 1 male, Teheran, near the pass above Polour, at $2350 \mathrm{~m}$ alt., Alborz Mountains, 30.VI.1978; 1 female and 1 male, Fasham, a branch valley, at $2500 \mathrm{~m}$ alt., 5.VII.1978 - for all specimens, J. Martens and H. Pieper leg. (SMF).

Note. Body and palpal organ of a male from Teheran are illustrated (Figs. 26-29).

Distribution. Europe, Mediterranean regions, Syria, Caucasus and Iran.

\section{Xysticus gallicus Simon 1875}

(Figs. 30-36)

Specimens examined. 1 female, 1 male and 1 juvenile, Azerbaijan, Kalan, Arasbaran Wildlife Refuge, between 2450 and $2650 \mathrm{~m}$ alt., meadow, 6-10.VI.1978, J. Martens and H. Pieper leg. (SMF).

Description based on the specimens from Iran. Measurements. Body length female $6.0 \mathrm{~mm}$, male $5.8 \mathrm{~mm}$; prosoma length female $2.6 \mathrm{~mm}$, male $2.9 \mathrm{~mm}$, width female $2.5 \mathrm{~mm}$, male $2.8 \mathrm{~mm}$; opisthosoma length female $3.6 \mathrm{~mm}$, male $3.1 \mathrm{~mm}$, width female $2.6 \mathrm{~mm}$, male $2.6 \mathrm{~mm}$; lengths

Figs. 30-48 (on the page 115). Xysticus spp. 30-36, Xysticus gallicus Simon 1875; 37-48, Xysticus logunovi Ono \& Martens, sp. nov.: 37, 43-45, a female paratype from Alasht, $1400 \mathrm{~m}$ alt., 38, 46-48, a female paratype from Alamdeh, $1450 \mathrm{~m}$ alt., 39-42, male holotype.30, 37, Female body, dorsal view; 31, 38, 39, male body, dorsal view; 32, 40, male palp, ventral view; 33, 41, male palp, retrolateral view; 34, 43, 46, epigynum; 35, 44, 47, female internal genitalia, ventral view; 36, 45, 48, female internal genitalia, dorsal view; 42, tegular apophyses of male palp, axial view. [Scales: 30-31, 37-39, $1 \mathrm{~mm}$; 32-36, 40-48, $0.25 \mathrm{~mm}$.] 

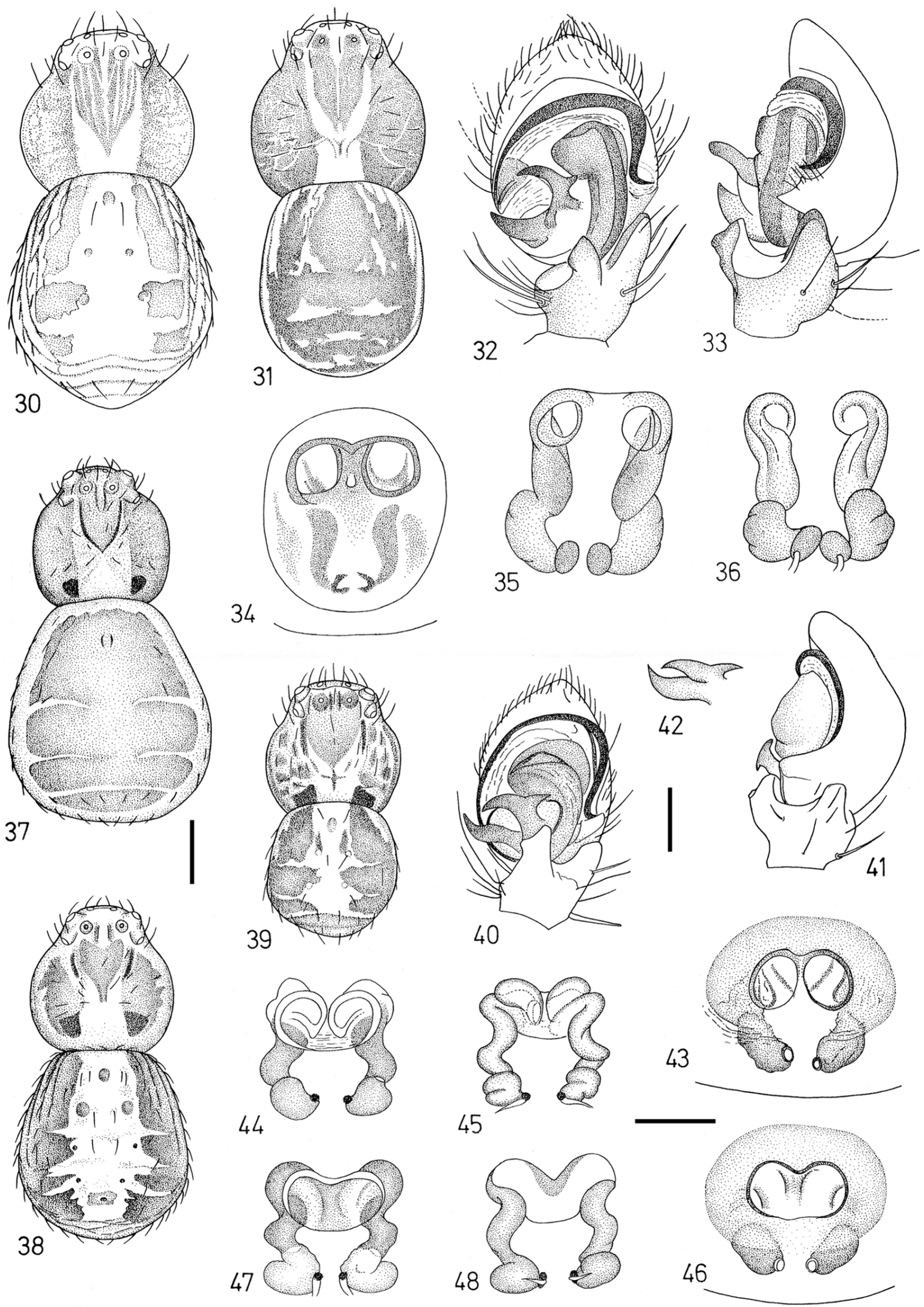
of legs [total length (femur + patella + tibia + metatarsus + tarsus)]: female, I $8.44 \mathrm{~mm}(2.56+1.28+1.88+1.76+$ $0.96)$, II $8.32 \mathrm{~mm}(2.48+1.28+1.84+1.76+0.96)$, III $5.44 \mathrm{~mm} \quad(1.84+0.80+1.12+1.04+0.64)$, IV $6.28 \mathrm{~mm}$ $(2.12+0.84+1.32+1.28+0.72)$, male I $9.92 \mathrm{~mm}(2.92+$ $1.28+2.20+2.40+1.12)$, II $9.60 \mathrm{~mm}(2.84+1.20+2.16+$ $2.28+1.12)$, III $6.44 \mathrm{~mm}(2.12+0.88+1.36+1.32+0.76)$, IV $6.52 \mathrm{~mm}(2.08+0.88+1.40+1.40+0.76)$.

Prosoma longer than wide (length/width female 1.04, male 1.03), with thin setae. Eyes: ALE $>$ PLE $>$ PME $=$ AME, ALE/AME female 1.71, male 1.75, PLE/PME female 1.43, male 1.50, AME-AME/AME-ALE female 1.70, male 1.77, PME-PME/PME-PLE female 1.00, male 0.94, median ocular area wider than long (length/width female 0.82 , male 0.87), wider behind than in front (anterior width/posterior width female and male 0.96), clypeus/AME-AME female 0.70 , male 0.63 . Labium longer than wide (length/width female 1.20, male 1.30), sternum longer than wide (length/width female 1.26, male 1.17). Leg formula I-II-IV-III; tarsal claws of legs I-II with 4 teeth, III-IV with 3 or 4 teeth.

Spination of leg I. Female: Femur: prolateral 1-1-1; tibia: ventral 2-2-2-2-2; metatarsus prolateral 1-1-2ap, retrolateral 1-1-1ap, ventral 2-2-2-2. Male: Femur: dorsal 0-1-1-1, prolateral $1-1-2-1-2-0$; tibia: prolateral $0-1-1$, retrolateral 1-1-1, ventral 2-2-2-2; metatarsus: prolateral 0-1-2ap, retrolateral 1-1-1ap, ventral 2-2-0-2-0.

Male palp (Figs. 32-33). Tibia with a ventral and a retrolateral apophysis: the ventral apophysis digitiform, the distal part slightly curved; the retrolateral one simple, distally sclerotized. Bulb small, with two apophyses, both rostriform and almost same in size, basal one proximally with a tooth; embolus long and thick, apically curved and sharpened.

Opisthosoma longer than wide (length/width female 1.38, male 1.19).

Female genitalia (Figs. 34-36). Epigynum longer than wide, with median septum between both the intromittent orifices; intromittent orifices visible. Intromittent canal thick, extending caudad, visible in dorsal view of the genitalia; spermathecae reniform, with large cock.

Coloration and markings (Figs. 30-31). Female: Prosoma beige, light blackish brown at the sides, lighter at the middle, chelicerae, maxillae, labium, palps and legs yellowish brown, sternum dull white; opisthosomal dorsum beige with distinct blackish brown markings, venter also beige. Male: Prosoma blackish brown, with V-shaped white region at the middle, chelicerae, maxillae, labium and palps yellowish brown, sternum dull white, femur and patella of legs I and II dark brown, other segments of legs I and II and all segments of legs III-IV yellowish brown, mottled with brown. Opisthosomal dorsum blackish brown, with indistinct white markings.

Distribution. Regions other than Iran are southern and eastern Europe to Hungary, European Russia, and Asia Minor.
Xysticus logunovi sp. nov.

(Figs. 37-48)

Type material. Holotype male, Masandaran, Klard, $20 \mathrm{~km} \mathrm{~S}$ of Amol, at $500 \mathrm{~m}$ alt., 24.V.1978; 1 male paratype, Masandaran, E of Suldeh, Caspian coast, at the sea level, evergreen forest, 22.V.1978; 2 males paratypes, Masandaran, $15 \mathrm{~km} \mathrm{E} \mathrm{of} \mathrm{Alasht,}$ at $910 \mathrm{~m}$ alt., 28.VI.1978; 1 female paratype (used for description), Masandaran, $11 \mathrm{~km}$ E of Alasht, a western branch valley, at $1400 \mathrm{~m}$ alt., 27-28.VI.1978; 1 female paratype, Masandaran, $\mathrm{S}$ of Alamdeh, at $1450 \mathrm{~m}$ alt., 27-30.V.1978 - for all specimens, J. Martens and H. Pieper leg. (SMF).

Diagnosis. This new species is closely related to Xysticus cor Canestrini 1873, distributed in southern Europe (Spain, Portugal, France, Switzerland, Austria, Italy and Hungary), but is distinguishable from the latter by the shape of male palp and the structure of female genitalia. The median tegular apophysis of the new species is smaller than that of Xysticus cor (cf. Figs. 40, 42 and Thaler \& Noflatscher 1990, p. 184, fig. 42). In female genitalia of Xysticus logunovi, intromittent canals are longer and spermathecae are much smaller than those of $X$. cor, while $X$. cor has shorter canals and larger spermathecae (cf. Figs. 44-48 and Thaler \& Noflatscher 1990, p. 184, fig. 44).

Description based on the male holotype and a female paratype from Alasht, $1400 \mathrm{~m}$ alt. Measurements. Body length female $5.5 \mathrm{~mm}$, male $4.1 \mathrm{~mm}$ (variation in body length female 4.9-5.5 mm, male 3.7-4.9 mm); prosoma length female $2.1 \mathrm{~mm}$, male $2.2 \mathrm{~mm}$, width female $2.0 \mathrm{~mm}$, male $2.0 \mathrm{~mm}$; opisthosoma length female $3.4 \mathrm{~mm}$, male 2.2 $\mathrm{mm}$, width female $3.1 \mathrm{~mm}$, male $2.0 \mathrm{~mm}$; lengths of legs [total length (femur + patella + tibia + metatarsus + tarsus)]: female, I $5.49 \mathrm{~mm}(1.65+0.90+1.20+1.14+0.60)$, II 5.40 $\mathrm{mm}(1.68+0.90+1.14+1.02+0.66)$, III $3.69 \mathrm{~mm}(1.26+$ $0.66+0.75+0.54+048)$, IV $4.05 \mathrm{~mm}(1.32+0.66+0.84$ $+0.69+0.54)$, male I $7.00 \mathrm{~mm}(2.04+0.92+1.52+1.68$ $+0.84)$, II $7.04 \mathrm{~mm}(2.08+0.92+1.56+1.64+0.84)$, III $4.60 \mathrm{~mm} \quad(1.48+0.56+1.04+0.92+0.60)$, IV $4.84 \mathrm{~mm}$ $(1.52+0.60+1.08+1.00+0.64)$.

Prosoma longer than wide (length/width female 1.03, male 1.10), with long, blunt setae. Eyes: ALE $>$ PLE $>$ $\mathrm{AME} \geqq \mathrm{PME}, \mathrm{ALE} / \mathrm{AME}$ female 3.00, male 1.86, PLE/PME female 2.00, male 1.66, AME-AME/AME-ALE female 1.66, male 1.86, PME-PME/PME-PLE female 0.92 , male 0.83 , median ocular area wider than long (length/width female 0.94 , male 0.89), wider behind than in front or median ocular area rectangular (anterior width/posterior width female 0.94, male 1.00), clypeus/AME-AME female 0.60 , male 0.61. Labium longer than wide (length/width female 1.27, male 1.25), sternum longer than wide (length/width female 1.14, male 1.23). Leg formula I-II-IV-III or II-I-IVIII; tarsal claws of legs I-II with 4 teeth, III-IV with 2 or 3 teeth.

Spination of leg I. Female: Femur: prolateral 1-2-2; tibia: ventral 1-2-2-2; metatarsus pro- and retrolateral $0^{-} 1^{-}$ 

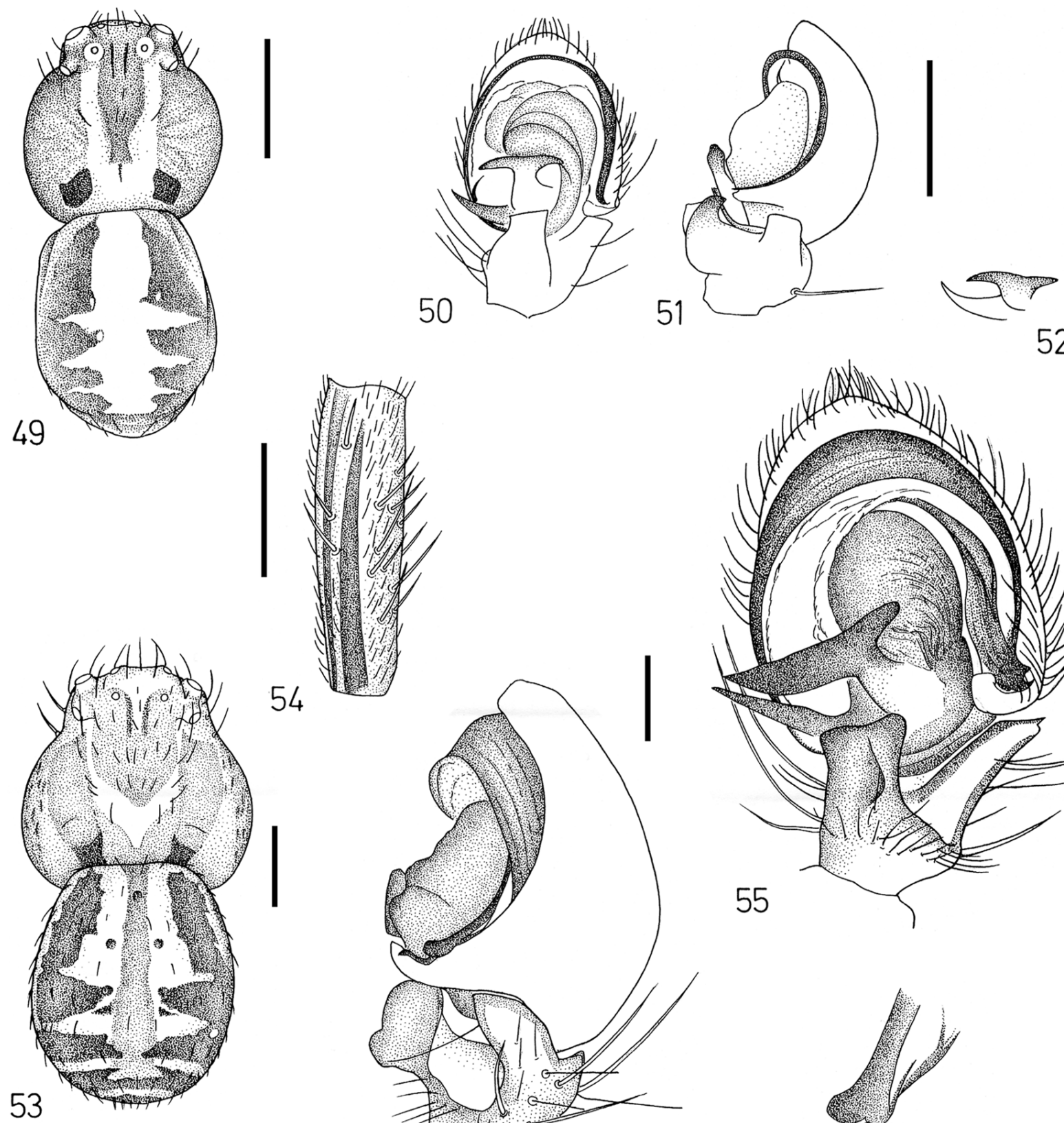

52
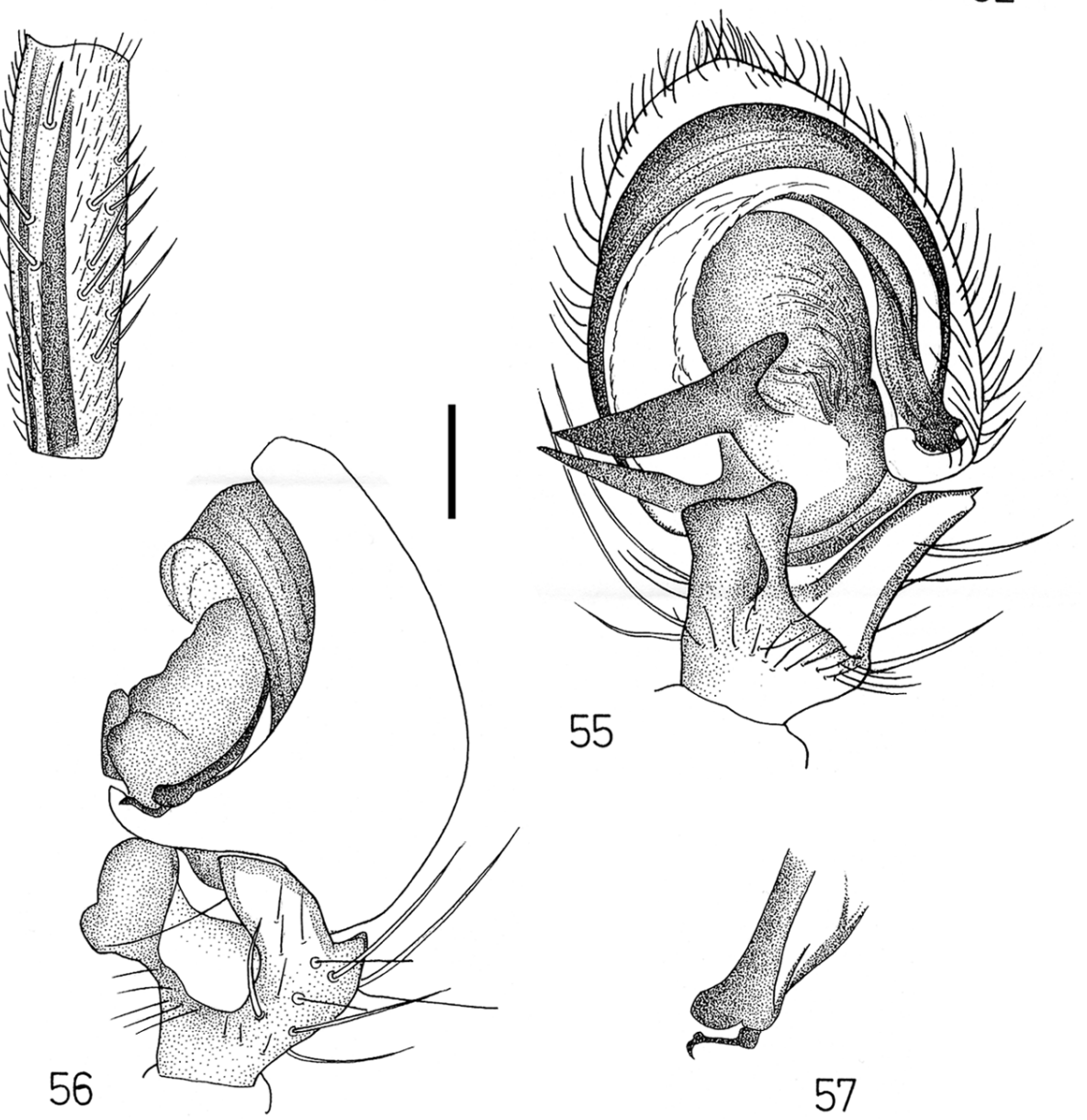

Figs. 49-57. Xysticus spp. 49-52, Xysticus kulczynskii Wierzbicki 1902; 53-57, Xysticus pieperi Ono \& Martens, sp. nov., male holotype from Azerbaijan - 49, 53, Male body, dorsal view; 50, 55, male palp, ventral view; 51, 56, male palp, retrolateral view; 52, tegular apophyses of male palp, ventral view; 54, femur of the first leg of male, dorsal view; 57, tip of embolus of male palp, axial view. [Scales: $49,53-54,1 \mathrm{~mm} ; 50-52,55-57,0.25 \mathrm{~mm}$.]

2ap respectively, ventral 2-2-0. Male: Femur: dorsal 1-11, prolateral $1-1-1-2-2-0$; tibia: pro- and retrolateral $1-1-0$ respectively, ventral 2-2-2-2; metatarsus: prolateral $0-1-$ 2ap, retrolateral $0-1-1$ ap, ventral $2-2-0$.

Male palp (Figs. 40-42). Tibia with a ventral and a retrolateral apophysis: the ventral apophysis digitiform; the retrolateral one simple and low. Bulb small, with two apophyses, both rostriform and almost same in size, basal one proximally with a pointed tooth, the distal one long and curved; embolus long and thin, apically curved and the tip not visible in ventral view.

Opisthosoma longer than wide (length/width female 1.09, male 1.10).

Female genitalia (Figs. 43-45). Epigynum wider than long, without distinct median septum between both the intromittent orifices; opening part wide, intromittent orifices visible. Intromittent canal thick, curved and extending caudad, visible in dorsal view of the internal genitalia; 
spermathecae small, ovate and with small cock. Although the opening part of epigynum of a female paratype from Alamdeh $1450 \mathrm{~m}$ alt. has no median septum (Fig. 46), differences were not found in the internal organs (Figs. 47-48).

Coloration and markings (Figs. 37, 39). Female: Prosoma light yellowish brown, lighter at the middle, chelicerae, maxillae and labium light yellowish brown, sternum yellowish brown mottled with white, palps and legs light yellowish brown, mottled with white; opisthosomal dorsum light yellowish brown, lighter at the middle with white lines at the sides, venter beige, spinnerets yellow. A female paratype (Fig. 38) from Alamdeh, $1450 \mathrm{~m}$ alt. shows markings of opisthosoma similar to those of the male holotype. Male: Prosoma blackish brown, with V-formed white region at the middle and a pair of large black spots on the posterior declivity, chelicerae, maxillae and labium brown, sternum brown and darker marginated, palps yellowish brown, femur and patella of legs I and II brown mottled with black, other segments of legs I and II and all segments of legs III-IV yellowish brown, mottled with blackish brown; opisthosomal dorsum purplish brown, with distict light-coloured marking.

Distribution. Iran (known only from type area).

Remarks. This species is dedicated to Dr. Dmitri V. Logunov, in honor of his contribution in taxonomy of crab spiders.

\section{Xysticus kulczynskii Wierzbicki 1902}

(Figs. 49-52)

Specimens examined. 1 male, $\mathrm{N}$ of Teheran, from DashtNazir, between 1000 and $1300 \mathrm{~m}$ alt., Alborz Mountains, 26.V.1978, J. Martens and H. Pieper leg. (SMF).

Comparative material. Xysticus ferrugineus (Menge 1876), 1 male from Germany, Laurenberg, Nassau, 25.IX.1909, Zimmermann leg., Coll. R. Braun (SMF).

Notes. This species was recently revised by Logunov, Marusik and Koponen (2002) and clearly separated from Xysticus ferrugineus (Menge 1876). The present authors came to the same conclusion based on a comparison of Iranian and German specimens.

Description of male based on a male specimen from Iran. Measurements. Body length $3.1 \mathrm{~mm}$; prosoma length 1.6 $\mathrm{mm}$, width $1.5 \mathrm{~mm}$; opisthosoma length $1.6 \mathrm{~mm}$, width 1.5 $\mathrm{mm}$; lengths of legs [total length (femur + patella + tibia + metatarsus + tarsus)]: I $5.72 \mathrm{~mm}(1.68+0.72+1.28+1.32$ $+0.72)$, II $5.52 \mathrm{~mm}(1.64+0.68+1.20+1.28+0.72)$, III $3.76 \mathrm{~mm} \quad(1.20+0.52+0.84+0.72+0.48), \quad$ IV $3.92 \mathrm{~mm}$ $(1.20+0.48+0.88+0.84+0.52)$.

Prosoma longer than wide (length/width 1.07), with thin setae. $\quad$ Eyes: ALE $>$ PLE $>$ PME $=$ AME, ALE/AME 1.83,
PLE/PME 1.33, AME-AME/AME-ALE 1.80, PMEPME/PME-PLE 0.83, median ocular area wider than long (length/width 0.87), wider behind than in front (anterior width/posterior width 0.93), clypeus/AME-AME 0.67 . Labium longer than wide (length/width 1.40), sternum longer than wide (length/width 1.05). Leg formula I-II-IVIII; tarsal claws of legs I-II with 4 teeth, III-IV with 3 teeth.

Spination of leg I. Femur: dorsal $0^{-} 1^{-1} 1^{-1}$, prolateral $1^{-}$ $1-1$; tibia: prolateral $1-1-1$, retrolateral $0-1-0$, ventral $2-2-$ $2-2$; metatarsus pro- and retrolateral $0^{-} 1^{-}$lap respectively, ventral 2-2.

Male palp (Figs. 50-52). Tibia with a ventral and a retrolateral apophysis: the ventral apophysis very wide; the retrolateral one simple and short. Bulb small, with two apophyses, both rostriform and almost same in size, basal one long and proximally with a pointed tooth, the distal one long and pointed; embolus long and thin, apically curved and the tip visible in ventral view.

Opisthosoma longer than wide (length/width 1.06).

Coloration and markings (Fig. 49). Prosoma brown at the sides, light yellowish brown at the middle, with a pair of large spots in the posterior part, chelicerae, maxillae and labium yellowish brown, sternum light beige mottled with blackish brown, legs and palps yellowish brown, mottled with black. Opisthosomal dorsum dull white, beige at the sides, with distinct marking, venter light beige mottled with blackish brown.

Distribution. Iran and Azerbaijan.

\section{Xysticus pieperi sp. nov.}

(Figs. 53-57)

Type material. Holotype male and 1 male paratype, Azerbaijan, Kalan, Arasbaran Wildlife Refuge, between 2450 and $2650 \mathrm{~m}$ alt., meadow, 6-10.VI.1978, J. Martens and H. Pieper leg. (SMF).

Other specimens examined. 1 juvenile, same data as for the holotype (SMF).

Diagnosis. This new species is closely allied to Xysticus edax (O. Pickard-Cambridge 1872) known from Israel, but can be distinguished from the latter by the details of male palpal organ. The median tegular apophysis of Xysticus pieperi is much larger and the embolus is much thicker than those of X. edax (cf. Figs. 55-56 and Levy 1976, p. 21, figs. $33-34$ or 1985 , p. 93, figs. 138-139). The tip of embolus of this new species is unique in shape (Fig. 57).

Description based on the male holotype (female unknown). Measurements. Body length $5.2 \mathrm{~mm}$; prosoma length $2.6 \mathrm{~mm}$, width $2.5 \mathrm{~mm}$; opisthosoma length $2.8 \mathrm{~mm}$, width $2.2 \mathrm{~mm}$; lengths of legs [total length (femur + patella + tibia + metatarsus + tarsus $)]:$ I $8.44 \mathrm{~mm} \quad(2.40+1.24+$

Figs. 58-70 (on the page 119). Oxyptila spp. 58-64, Oxyptila nigrita Thorell 1875; 65-67, Oxyptila makidica Ono \& Martens, sp. nov.; 68-70, Oxyptila lutosa Ono \& Martens, sp. nov. - 58, 65, 68, Female body, dorsal view; 59, male body, dorsal view; 60, male palp, ventral view; 61, male palp, retrolateral view; 62, 66, 69, epigynum; 63, female internal genitalia, ventral view; 64, 67, 70, female internal genitalia, dorsal view. [Scales: 58-59, 65, 68, $1 \mathrm{~mm} ; 60^{-64}, 66^{-67}, 69-70,0.25 \mathrm{~mm}$.] 

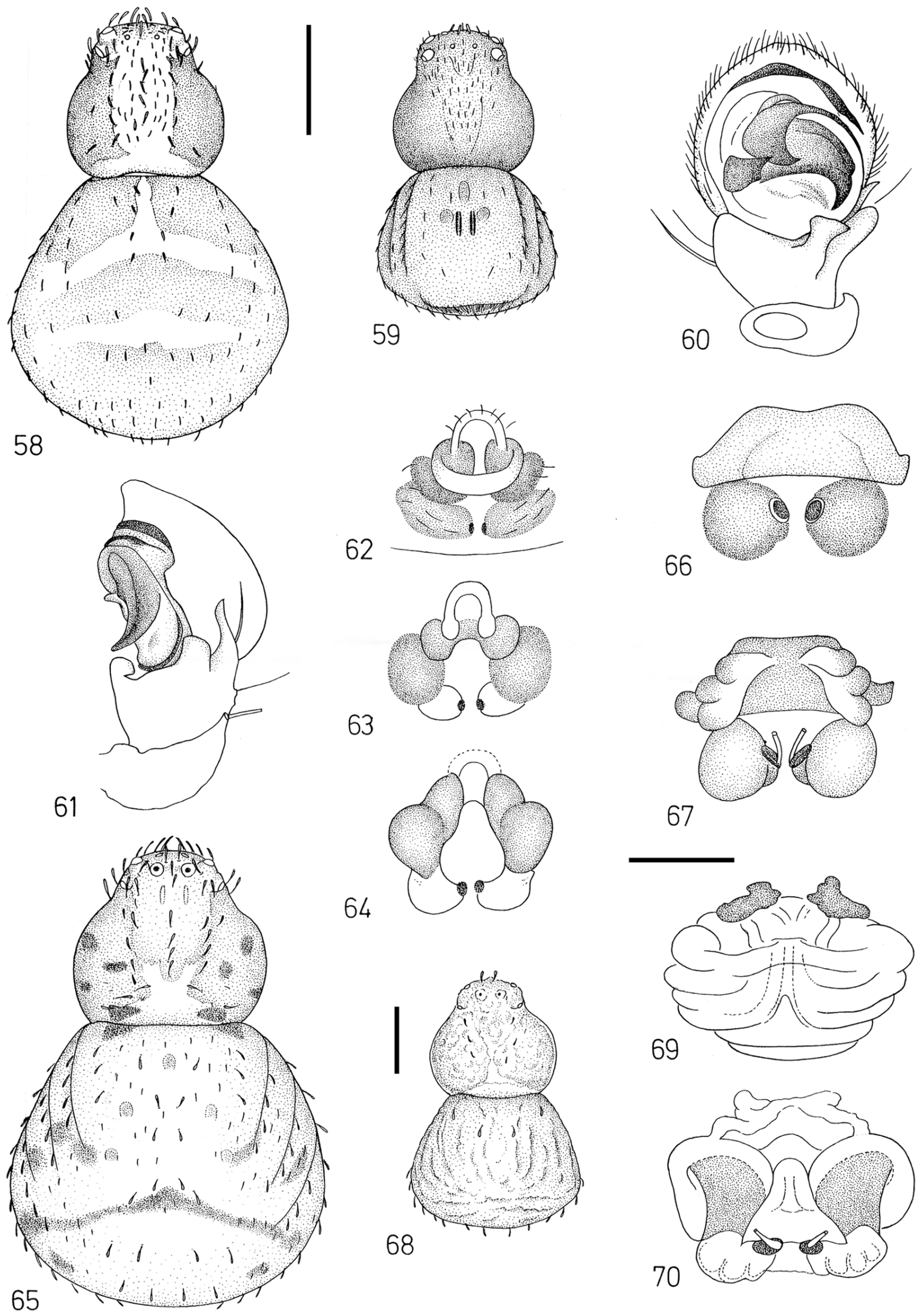

63
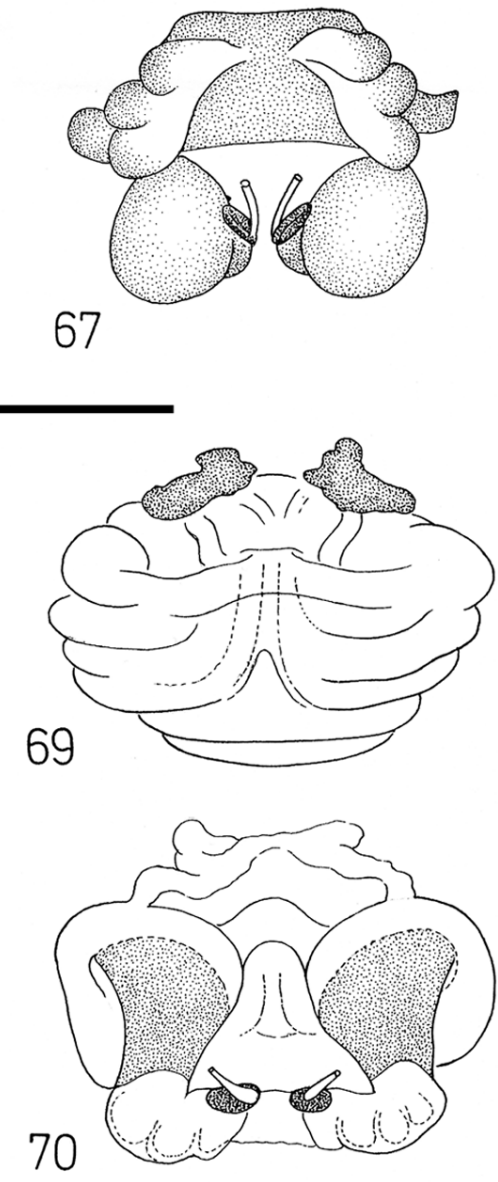
$1.84+1.92+1.04)$, II $8.56 \mathrm{~mm}(2.52+1.24+1.84+1.92+$ $1.04)$, III $5.80 \mathrm{~mm}(1.80+0.96+1.20+1.12+0.72)$, IV $5.96 \mathrm{~mm}(1.88+0.92+1.24+1.20+0.72)$.

Prosoma longer than wide (length/width 1.04), with thin setae. Eyes: ALE $>$ PLE $>$ PME $=$ AME, ALE $/$ AME 1.75, PLE/PME 1.50, AME-AME/AME-ALE 1.78, PME-PME/ PME-PLE 1.00, median ocular area wider than long (length/ width 0.91), wider behind than in front (anterior width/posterior width 0.95), clypeus/AME-AME 0.75. Labium longer than wide (length/width 1.30), sternum longer than wide (length/width 1.19). Leg formula II-I-IV-III; tarsal claws of legs I-IV with 4 teeth.

Spination of leg I. Femur: dorsal $0^{-} 0^{-} 1^{-1} 1^{-} 0^{-1}$, prolateral 11 irregularly (Fig. 54); tibia: pro- and retrolateral 1-1-1, ventral 2-2-2-2; metatarsus: prolateral 1-1-2 ap, retrolateral 1-1-1ap, ventral 2-2-2.

Male palp (Figs. 55-57). Tibia with a ventral and a retrolateral apophysis, both strongly sclerotized: the ventral apophysis very wide and angular; the retrolateral one long and pointed. Bulb small, with two apophyses, the basal one larger and hammer-shaped, the distal one spiniform and pointed; embolus long and wide, apically with a hookshaped process.

Opisthosoma longer than wide (length/width 1.27).

Coloration and markings (Fig. 53). Prosoma laterally brown, light yellowish brown with a V-shaped white marking at the middle and a pair of large spots in the posterior part, chelicerae, maxillae and labium light brown, sternum dull white mottled with brown, legs and palps yellowish brown, mottled with brown. Opisthosomal dorsum dull white, blackish brown at the sides, with distinct marking, venter light beige.

Distribution. Iran (known only from type locality).

Remark. This species is dedicated to Dr. Harald Pieper, a good friend of J. Martens and the only other participant of the 1978 Iran Expedition.

\section{Genus Oxyptila Simon 1864, sensu lato}

\section{Oxyptila nigrita Thorell 1875}

(Figs. 58-64)

Specimens examined. 1 female, 1 male and 1 juvenile, Makidi, at $1700 \mathrm{~m}$ alt., Azerbaijan, oak bush, 13.VI.1978, J. Martens and H. Pieper leg. (SMF).

Note. Body and genital organs of both the sexes are illustrated based on the Iranian material (Figs. 58-64).

Distribution. Iran; from northern Europe to Russia and Balkan Peninsula.

Remarks. In the present paper, Oxyptila with correct Latinization as Thorell's amendment is used for the name of the genus as the European and Japanese tradition, although Ozyptila as the original spelling should stand according to the present rules of ICZN as explained in Ono (1988). Both the names have been historically used in parallel with swaying usage in the catalogues (Ozyptila may have been more used since1989). An immediate decision of this question by the International Commission on of Zoological Nomenclature is expected.

\section{Oxyptila makidica sp. nov.}

(Figs. 65-67)

Type material. Holotype female, Azerbaijan, Makidi, at 1700 m alt., oak bush, 13.VI.1978, J. Martens and H. Pieper leg.; 1 female paratype, same area and same collectors, at $1650 \mathrm{~m}$ alt., 11.VI.1978 (SMF).

Other specimens examined. 1 juvenile, same data as for the holotype (SMF).

Diagnosis. This new species belongs to a species group with larger body and relatively light markings and resembles Oxyptila trux (Blackwall 1846), O. atomaria (Panzer 1801), O. simplex (O. Pickard-Cambridge 1862) and $O$. blackwalli Simon, 1875 in general appearance, but can be readily distinguished from these species by the shape of epigynum with a huge sclerotized plate in the anterior part.

Description based on the female holotype (male unknown). Measurements. Body length $4.18 \mathrm{~mm}$; prosoma length $1.72 \mathrm{~mm}$, width $1.72 \mathrm{~mm}$; opisthosoma length 2.60 $\mathrm{mm}$, width $2.76 \mathrm{~mm}$; lengths of legs [total length (femur + patella + tibia + metatarsus + tarsus)]: I $4.14 \mathrm{~mm}(1.28+$ $0.72+0.80+0.76+0.58)$, II $4.26 \mathrm{~mm}(1.32+0.72+0.84+$ $0.80+0.58)$, III $2.96 \mathrm{~mm}(0.92+0.52+0.60+0.52+0.40)$, IV $3.04 \mathrm{~mm}(0.96+0.48+0.68+0.48+0.44)$.

Prosoma as long as wide (length/width 1.00), covered with clavate setae and hairs. Eyes: ALE $>$ PLE $>$ PME $>$ AME, ALE/AME 2.33, PLE/PME 2.00, AME-AME/AMEALE 1.67, PME-PME/PME-PLE 0.77, median ocular area wider than long (length/width 0.81), narrower behind than in front (anterior width/posterior width 1.05), clypeus/AMEAME 0.60. Labium longer than wide (length/width 1.40), sternum longer than wide (length/width 1.16). Leg formula II-I-IV-III; tarsal claws of legs I-III with 3 teeth, IV with 2 teeth.

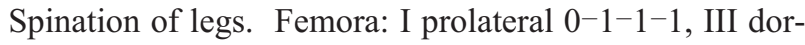
sal 1-0; patella: IV retrolateral 1 ; tibiae: I-IV dorsal $1-1-0$, I-II ventral 2-2; metatarsi: I-II pro- and retrolateral $0^{-} 1^{-}$ 1ap respectively, ventral $2-2$.

Opisthosoma wider than long (length/width 0.94), with short clavate hairs.

Female genitalia (Figs. 66-67). Epigynum: Intromittent orifices covered by a large sclerotized plate, but without a distinct hood. Intromittent canal thick, short and tuberculated; spermathecae globular, with small cock.

Coloration and markings (Fig. 65). Prosoma brown at the sides, light yellowish brown at the middle, with small Ushaped white marking and a pair of dark brown spots in the posterior part; chelicerae, maxillae and sternum yellowish brown, labium brown, legs I and II brown, legs III and IV and palps yellowish brown. Opisthosomal dorsum beige with black spots, but without distinct marking, venter light beige mottled with blackish brown. 
Variation. The single female paratype: body length 3.20 $\mathrm{mm}$, prosoma length $1.52 \mathrm{~mm}$, width $1.48 \mathrm{~mm}$, opisthosoma length $1.80 \mathrm{~mm}$, width $2.24 \mathrm{~mm}$.

Distribution. Iran (known only from type locality).

Remark. The specific name is derived from the type area.

\section{Oxyptila lutosa sp. nov.}

(Figs. 68-70)

Type material. Female holotype, Azerbaijan, Makidi, at $1650 \mathrm{~m}$ alt., oak bush, 11.VI.1978, J. Martens and H. Pieper leg. (SMF).

Diagnosis. This new species resembles Oxyptila scabricula (Westring 1851) distributed widely in Europe and O. fukushimai recently described by Ono (2002) from Japan, but can be distinguished from these species by the shape of epigynum, which is unique in having central hood situated in the posterior part.

Description based on the female holotype. Measurements. Body length $3.80 \mathrm{~mm}$; prosoma length $1.72 \mathrm{~mm}$, width $1.68 \mathrm{~mm}$; opisthosoma length $2.20 \mathrm{~mm}$, width 2.68 $\mathrm{mm}$; lengths of legs [total length (femur + patella + tibia + metatarsus + tarsus $)$ ]: I $4.28 \mathrm{~mm}(1.24+0.76+0.88+0.88$ $+0.52)$, II $4.04 \mathrm{~mm}(1.24+0.72+0.80+0.80+0.48)$, III $2.72 \mathrm{~mm} \quad(0.84+0.52+0.52+0.48+0.36)$, IV $2.92 \mathrm{~mm}$ $(1.00+0.52+0.56+0.52+0.32)$.

Prosoma longer than wide (length/width 1.02), covered with mud, setae clavated. Eyes: ALE $>$ PLE $>$ PME $>$ AME, ALE/AME 1.83, PLE/PME 1.75, AME-AME/AMEALE 1.67, PME-PME/PME-PLE 0.71, median ocular area longer than wide (length/width 1.13), narrower behind than in front (anterior width/posterior width 1.23), clypeus/AMEAME 0.80. Labium longer than wide (length/width 1.40), sternum longer than wide (length/width 1.14). Legs with clavate setae and hairs, leg formula I-II-IV-III; tarsi curved, tarsal claws of legs I-II with 3 teeth, III-IV with 2 teeth.

Spination of legs. Femora: I prolateral 1-1, II-III dorsal 1; tibiae: I-IV dorsal 1-1-0, I-II ventral 2-2; metatarsi: I-II pro- and retrolateral $0^{-1}-1$ ap respectively, ventral $2-2$.

Opisthosoma wider than long (length/width 0.82 ), with short clavate hairs.

Female genitalia (Figs. 69-70). Epigynum: Intromittent orifices visible in ventral view and covered with a large wrinkled plate. Central hood situated in the posterior part of epigynum. Intromittent canal thick, short and conical; spermathecae small and reniform, with small cock.

Coloration and markings (Fig. 68). Prosoma brown by nature but covered with gray mud; chelicerae brown, dorsally with a white marking, sternum light grayish brown mottled with black and white, maxillae, labium and coxae of legs light grayish brown, other segments of legs brown. Opisthosomal dorsum beige, mottled with black, but without distinct marking, ventral side gray.

Distribution. Iran (known only from type locality).
Remark. Specific name is Latin meaning dirty derived from the muddy body.

\section{Genus Synaema Simon 1864}

$$
\text { Synaema globosum (Fabricius 1775) }
$$

Specimens examined. 1 male, Masandaran, $25 \mathrm{~km} \mathrm{~S}$ of Amol, a western branch valley of Heraz, at $300 \mathrm{~m}$ alt., Alborz Mountains, 29.VI.1978; 1 male, same place, between 490 and $560 \mathrm{~m}$ alt., 29.VI.1978; 1 female, Masandaran, $12 \mathrm{~km} \mathrm{NW}$ of Zirab, altitude not recorded, 28.VI.1978 - for all specimens, J. Martens and H. Pieper leg. (SMF).

Distribution. Trans-Eurasian temperate regions.

$$
\text { Genus Heriaeus Simon } 1875
$$

Heriaeus spinipalpus Loerbroks 1983

(Figs. 71-74)

Specimens examined. 1 female, Alborz Mountains, Fasham, at $2350 \mathrm{~m}$ alt., 4.VII.1978, J. Martens and H. Pieper leg.(SMF).

Note. This single female specimen was assigned to this species by the shape of female genitalia with a large central hood (cf. Figs. 71-74; Loerbroks 1983, p. 123, figs. 67-68). Komposch (2002) recorded Heriaeus graminicola (Doleschall, 1852) from Iran.

Distribution. This species was recorded from Syria, Anatolia, Caucasus and Turkmenistan (Loerbroks 1983).

Genus Misumena Latreille 1804

\section{Misumena vatia (Clerck 1757)}

Specimens examined. 1 female, Azerbaijan, Makidi, at 1800 m alt., 13.VI.1978, J. Martens and H. Pieper leg. (SMF); 1 juvenile, Fasham, a branch valley, at $2500 \mathrm{~m}$ alt., 5. VII. 1978, J. Martens and H. Pieper leg. (SMF).

Distribution. Holarctic.

Genus Pistius Simon 1875

Pistius truncatus (Pallas 1772)

Specimen examined. 1 juvenile, Masandaran, $25 \mathrm{~km} \mathrm{~S}$ of Amol, a western branch valley of Heraz, between 490 and $560 \mathrm{~m}$ alt., 29.VI.1978, J. Martens and H. Pieper leg. (SMF).

Distribution. Europe, Mediterranean regions to European Russia (additional information in Buchar \& Thaler 1995).

\section{Genus Runcinia Simon 1875}

Runcinia lateralis (C. L. Koch 1838)

(Figs. 75-77) 


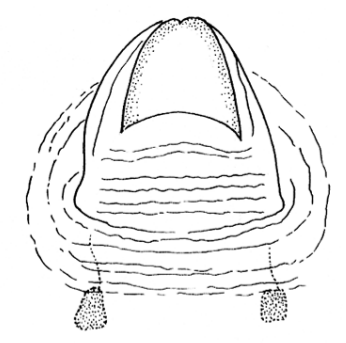

71
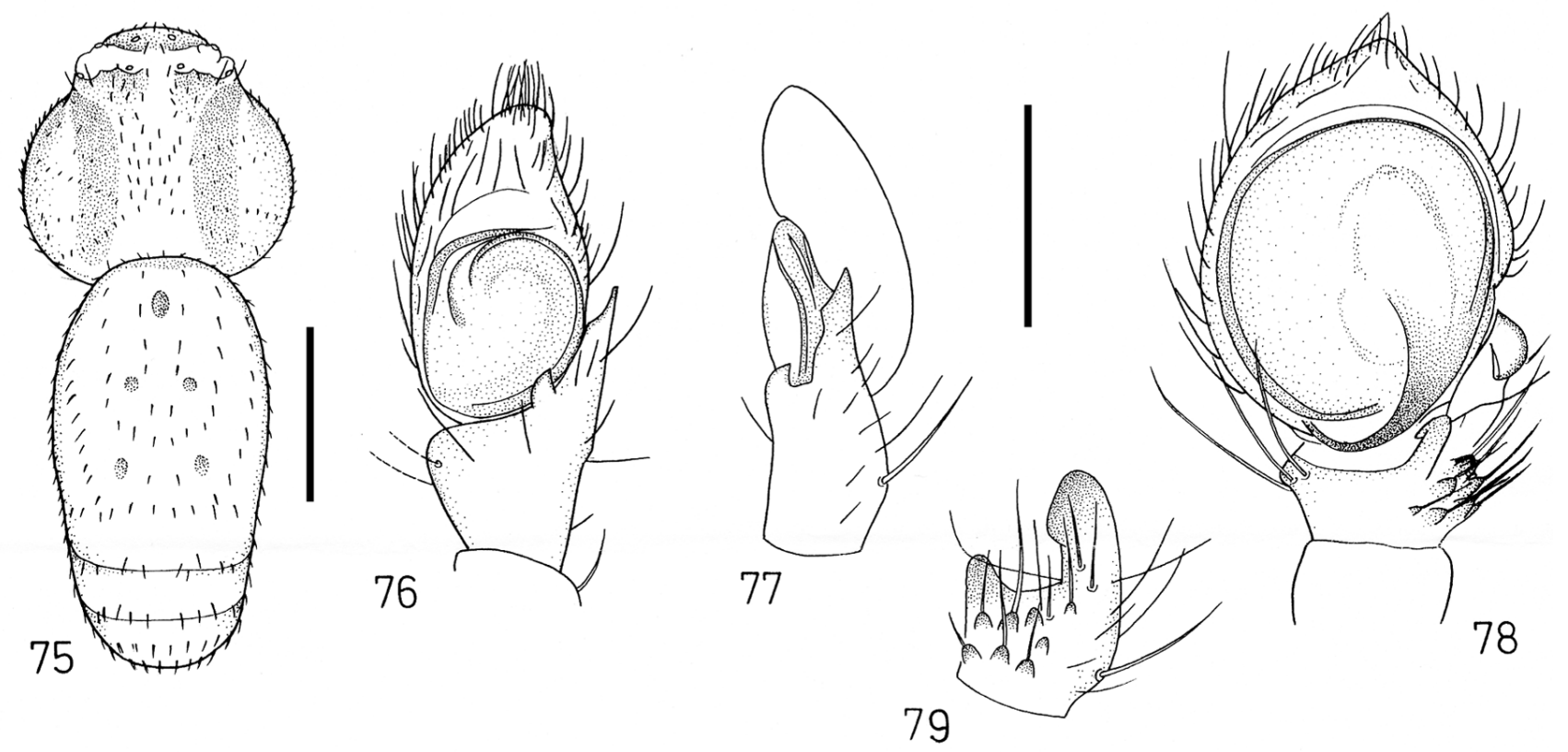

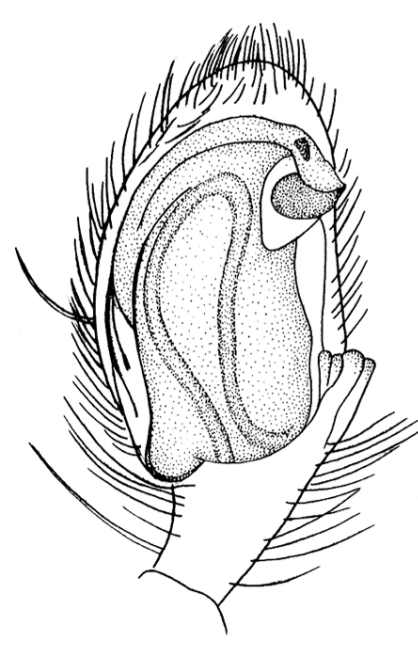

84

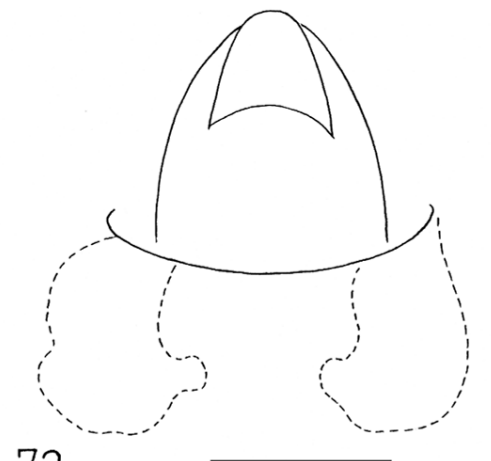

72

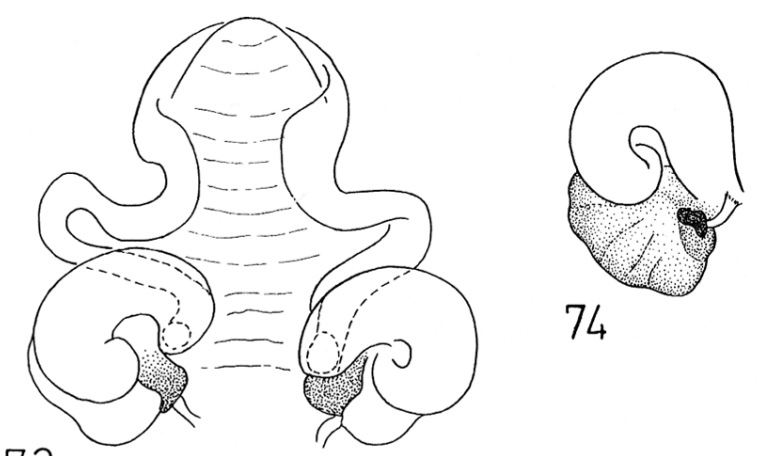

73

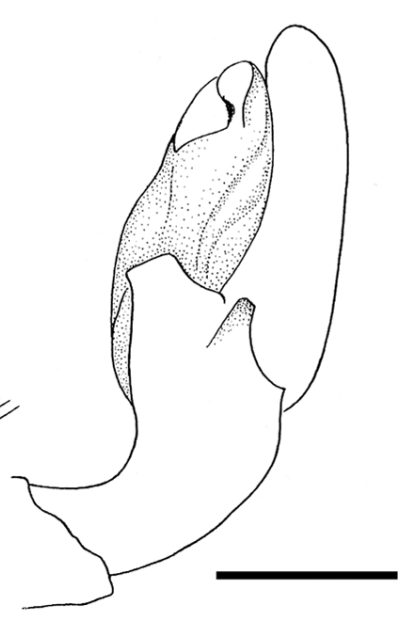

85

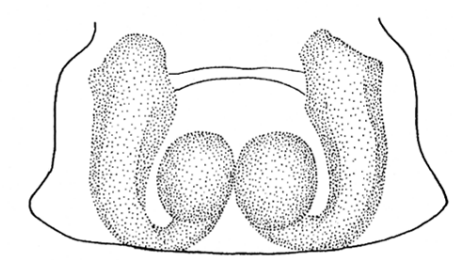

80

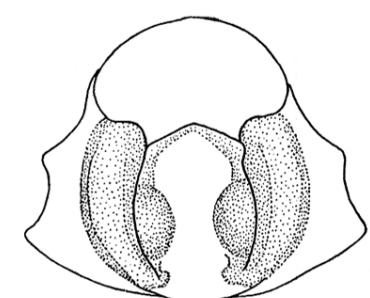

82

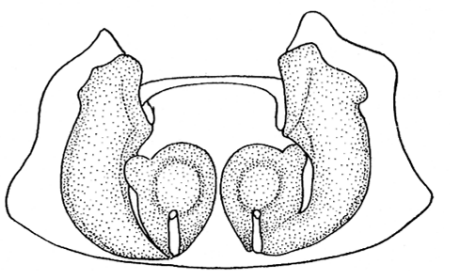

81

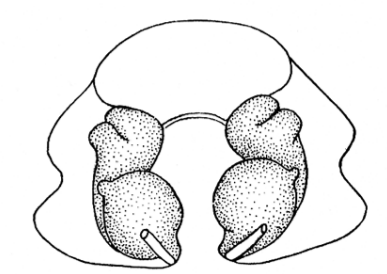

83

Figs. 71-85. 71-74, Heriaeus spinipalpus Loerbroks 1983; 75-77, Runcinia lateralis (C. L. Koch 1838); 78-79, Thomisus hilarulus Simon 1875; 80-81, Philodromus longipalpis Simon 1870; 82-83, Philodromus cespitum (Walckenaer 1802); 84-85, Philodromus emarginatus (Schrank 1803).-71, 80, 82, Epigynum; 72, central hood of epigynum, ventral view; 73, 81, 83, female genitalia, dorsal view; 74, main part of female genitalia, lateral view; 75, male body, dorsal view; 76, 78, 84, male palp, ventral view; 77, 85, male palp, retrolateral view; 79, tibia of male palp, retrolateral view. [Scales: 71-74, 76-85, $0.25 \mathrm{~mm} ; 75,1 \mathrm{~mm}$.] 
Specimens examined. 3 males, Masandaran, $25 \mathrm{~km} \mathrm{~S}$ of Amol, a western branch valley of Heraz, between 490 and $560 \mathrm{~m}$ alt., 29.VI.1978, J. Martens and H. Pieper leg. (SMF).

Note. Body and male palp (Figs. 75-77) are illustrated based on the Iranian material.

Distribution. Southern Europe, northern Africa, Middle East to China.

\section{Genus Thomisus Walckenaer 1805}

Thomisus hilarulus Simon 1875

(Figs. 78-79)

Specimens examined. 1 male and 2 immature females, Teheran Province, near the pass of Polour, at $2350 \mathrm{~m}$ alt., 30.VI.1978, J. Martens and H. Pieper leg. (SMF).

Notes. Although Thomisus onustus Walckenaer 1805, widespread from Europe to Siberia, Mongolia and China, T. zyuzini Marusik \& Logunov 1990, known from Uzbekistan, Turkmenistan, and Tajikistan (Marusik \& Logunov 1994) and the Mediterranean species T. hilarulus Simon 1875, closely resemble one another, the present specimen was identified to belong to the last species based on the arrangement of conical spines on the male palpal tibia (cf. Fig. 79, Commelini 1957, p.15, fig. 23 and Marusik \& Logunov 1995, p. 170, fig. 20). Roewer (1955) and Komposch (2002) recorded Thomisus onustus from Iran. Logunov (pers. comm.) suggsted that Thomisus hilarulus and $T$. onustus would be synonymous.

Distribution. France, Canary Islands, Libya, Tunisia, Syria, Anatolia and Iran.

\section{Family Philodromidae}

\section{Genus Philodromus Walckenaer 1826}

\section{Philodromus longipalpis Simon 1870}

(Figs. 80-81)

Specimens examined. 3 females and 3 juveniles, Masandaran, $25 \mathrm{~km} \mathrm{~S}$ of Amol, a western branch valley of Heraz, between 490 and $560 \mathrm{~m}$ alt., Alborz Mountains, 29.VI.1978, J. Martens and H. Pieper leg. (SMF).

Notes. This taxon was raised to species rank (Segers 1992) from a subspecies of Philodromus cespitum (Walckenaer 1802) defined by Braun (1965). Male palp is illustrated based on an Iranian specimen (Figs. 80-81).

Distribution. Other than Iran, this species is known from Spain, France, Turkey and Hungary.

\section{Philodromus cespitum (Walckenaer 1802)}

$$
\text { (Figs. 82-83) }
$$

Specimen examined. 1 female, Alborz Mountains, Fasham, at $2500 \mathrm{~m}$ alt., 5.VI.1978, J. Martens and H. Pieper leg. (SMF).

Note. Female genitalia (Figs. 82-83) are illustrated based on the above material.

Distribution. Holarctic.

\section{Philodromus emarginatus (Schrank 1803)}

(Figs. 84-85)

Specimen examined. 1 male, N Teheran, Dasht-Nazir, between 1000 and $1300 \mathrm{~m}$ alt., Iran, 26.V.1978, J.Martens and H. Pieper leg. (SMF).

Note. Male palpal organ (Figs. 84-85) is illustrated based on the Iranian material.

Distribution. Palearctic.

\section{Acknowledgments}

The expedition to Iran (J. Martens and H. Pieper) was sponsored by the Deutsche Forschungsgemeinschaft. J. Martens greatly acknowledges the excellent and permanent help of his friend Harald Pieper along this extended field trip. Feldbausch Stiftung and Wagner Stiftung at the Fachbereich Biologie of the University of Mainz kindly provided travel grants to J. Martens. The laboratory study was partly supported (for H. Ono) by the Grant-in-aid No. 16540431 for Scientific Research, and in traveling expenses for overseas research (1999 in Europe) by the Ministry of Education, Science, Sports and Culture, Japan. Peter Jäger, Frankfurt am Main, Yuri M. Marusik, Magadan, and Dmitri V. Logunov, Manchester, gave invaluable comments on draft of this paper. Christian Komposch, Graz, kindly gave information about Iranian spiders. Manfred Grasshoff, Frankfurt am Main, late Jacqueline Heurtault and Christine Rollard, Paris, kindly lent specimens. Yoshimi Watanabe, Tomoko Yoshida and Käthe Rehbinder, arranged illustrations. Both the authors wish to express their heartfelt thanks to all friends, colleagues and institutions above mentioned.

\section{References}

Azarkina, G. N. \& Logunov, D. V. 2001. Separation and distribution of Xysticus cristatus (Clerck, 1758) and X. audax (Schrank, 1803) in eastern Eurasia, with description of a new species from the mountains of Central Asia (Aranei: Thomisidae). Arthropoda Selecta, 9 (for 2000): 133-150.

Braun, R. 1965. Beitrag zu einer Revision der paläarktischen Arten der Philodromus aureolus-Gruppe (Arach., Araneae). I. Morphologisch-systematischer Teil. Senckenbergiana biol., 46: 369-428.

Buchar, J. \& Thaler, K. 1995. Zur Variation der Kopulationsorgane von Pistius truncatus (Pallas) (Arachnida, Thomisidae) in Mitteleuropa. Linzer biol. Beitr., 27: 653-663.

Commellini, A. 1957. Notes sur les Thomisidae d'Afrique. 2. Le genre Thomisus. Rev. Zool. Bot. Agr., 55: 1-32.

Crome, W. 1965. Studien an Krabbenspinnen (Araneae: Thomisidae). 5. Subspezifische Gliederung von Xysticus ninnii Thorell, 1872 und ein Versuch zur Zoogeographie der Unterarten. Deutsch. Entomol. Zeitschr., N. F., 12: 421-441.

Jantscher, E. 2001. Diagnostic characters of Xysticus cristatus, X. audax and X. macedonicus (Araneae: Thomisidae). Bull. Brit. Arachnol. Soc., 12: 17-25.

Komposch, Ch. 2002. Spinnen, Weberknechte, Skorpione und Walzenspinnen aus dem Iran (Arachnida: Araneae, Opiliones, Scorpiones, Solifudae), pp. 93-103. In: Gutleb, B. \& Wieser, Ch. (ed.) Ergebnisse einer zoologischen Exkursion in den Nordiran, 2001. Carinthia II, 192/112: 33-140.

Levy, G. 1976. The spider genus Xysticus (Araneae: Thomisidae) in Israel. Israel J. Zool., 25: 1-37.

Levy, G. 1985. Fauna Palaestina, Arachnida, II. Araneae: Thomisidae. 114 pp., 1 col. pl., 1 map. The Israel Academy of Sciences and Humanities, Jerusalem. 
Loerbroks, A. 1983. Revision der Krabbenspinnen-Gattung Heriaeus Simon (Arachnida: Araneae: Thomisidae). Verh. naturwiss. Ver. Hamburg, N.F., 26: 85-139.

Logunov, D. V. 1992. A review of the spider genus Tmarus Simon, 1875 (Araneae, Thomisidae) in the USSR fauna, with a description of new species. Sibirsk. Biol. Zhurn, (1): 61-73.

Logunov, D. V., Marusik, Y. M. \& Koponen, S. 2002. Redescription of a poorly known spider species, Xysticus kulczynskii Wierzbicki 1902 (Araneae: Thomisidae). Acta Arachnol., 51: 99-104.

Logunov, D. V., Marusik, Y. M. \& Mozaffarian, F. 2001. Faunistic review of the jumping spiders of Iran (Aranei: Salticidae). Arthropoda Selecta, 10: 155-167.

Marusik, Y. M., \& Logunov, D. V. 1990. The crab spiders of Middle Asia, USSR (Aranei, Thomisidae), 1. Descriptions and notes on distribution of some species. Korean Arachnol., 6: 31-62.

Marusik, Y. M., \& Logunov, D. V. 1995. The crab spiders of Middle Asia (Aranei, Thomisidae), 2. Beitr. Araneol., 4: 133-176.

Mozaffarian, F., \& Marusik, Y. M. 2001. A checklist of Iranian spiders (Aranei). Arthropoda Selecta, 10: 67-74.

Ono, H., 1988. A revisional study of the spider family Thomisidae (Arachnida, Araneae) of Japan. Natn. Sci. Mus. Monogr., Tokyo, 5: i-ii, 1-252, 1 col. pl.
Ono, H., 2002. New species of crab spiders (Araneae, Thomisidae) from Japan. Bull. Natn. Sci. Mus., Tokyo, Ser. A, 28: 201-210.

Roewer, C. F. 1955. Die Araneen der österreichischen IranExpedition 1949/50. Sitz.-ber. Akad. Wiss. (Mathem.-Naturw. K1.), Wien, Abt. I, 164: 751-782.

Segers, H. 1992. Nomenclatural notes on, and redescriptions of some little-known species of the Philodromus aureolus-group (Araneae: Philodromidae). Bull. Brit. Arachnol. Soc., 9: 19-25.

Thaler, K. \& Noflatscher, M. T. 1990. Neue und bemerkenswerte Spinnenfunde in Südtirol (Arachnida: Aranei). Veröffentl. Mus. Ferdinandeum, 69: 169-190.

Utotchkin, A. S. \& Savelyeva, L. G. 1995. Review of the spider genus Xysticus C. L. Koch, 1935 (Arachnida, Aranei, Thomisidae) in the East Kazakhstan Area. Arthropoda Selecta, 4: 65-69.

Wunderlich, J., 1994. Zur Kenntnis west-paläarktischer Arten der Gattungen Psammitis Menge 1875, Xysticus C. L. Koch 1835 und Ozyptila Simon 1864 (Arachnida: Araneae: Thomisidae). Beitr. Araneol., 4: 749-774.

(Literatures cited in the text only as authors of the scientific names were not given.)

Received October 31, 2004 / Accepted December 5, 2004 